\title{
ОПРЕДЕЛЕНИЕ ФТОРИДА В РАСТЕНИЯХ ПРИ ПОМОЩИ ФТОРИДСЕЛЕКТИВНОГО ЭЛЕКТРОДА
}

Основными источниками фтористых загрязнителей воздуха являются алюминиевая, суперфосфатная, стекольная, керамическая и химическая отрасли промышленности, в сырье которых входят фтористые соединения $\left[{ }^{1-4}\right]$. Последние, в частности газообразные $\left(\mathrm{HF}, \mathrm{SiF}_{4}\right)$ и водорастворимые частицы $\left(\mathrm{NaF}, \mathrm{Na}_{2} \mathrm{SiF}_{6}\right)$, нередко вызывают существенные повреждения растений $\left[{ }^{5-7}\right]$. Растения способны накапливать из воздуха фториды, и концентрация их в тканях растений может быть в тысячу раз выше, чем в окружающем воздухе. Такие растения, используемые в качестве корма, нередко вызывают заболевания сельскохозяйственных животных флюорозом $\left[{ }^{8-10}\right]$. Как правило, содержание фторида в кормах не должно превышать $1,5-2$ мг на 1 кг их сухого веса [1 ${ }^{11}$. По количеству фторида в растениях можно оценить загрязненность окружающего воздуха фтористыми соединениями, а также при необходимости принять меры, чтобы уберечь животных от заболевания флюорозом.

В настоящей р.аботе описывается методика определения количества фторида в растениях и приводятся некоторые результаты анализов.

\section{Методика}

Для суммарного определения фтористых соединений в воздухе, растениях и минеральных материалах фторсодержащая часть пробы переводится в водный раствор, в котором $\mathrm{F}$ - определяется колориметрическим способом $\left[{ }^{12-14}\right]$ или при помощи фторселективного электрода (селектродом) $\left[{ }^{15-17}\right]$.

Для определения фторида в растениях высушенная проба озоляется, а затем зола разлагается при помощи кислот. Выделенный фтористый водород дистиллируется и абсорбируется в жидкоєть, в которой определяется $\mathrm{F}^{-}$. Существуют некоторые сравнительно быстрые способы минерализации органического материала, например, озоление под давлением в кислородной бомбе $\left.{ }^{18}\right]$ или сжигание кислородом в специальной воронке, снабженной электродами [ $\left.{ }^{19}\right]$. Для дистилляции фтористого водорода, выделяющегося при разложении золы, применяются специальные автоматические приспособления $\left[{ }^{20}\right]$. Абсорбция проводится при длительной, до 24 , диффузии его в раствор гидроокиси натрия или в специальную пленку [18-22]. Хотя минерализация органического вещества идет быстро, анализ в целом из-за длительности абсорбции занимает много времени. Для определения фторида в фосфатах применяется разложение проб хлорной кислотой с последовательным определением $\mathrm{F}^{-}$в полученном растворе $\left[{ }^{23}\right]$. 
В работе применено разложение озоленных проб растений хлорной кислотой. Так как получаемый после нейтрализации раствор можно сразу же использовать для определения $\mathrm{F}^{-}$селектродом, отпадает необходимость в длительном процессе дистилляции-абсорбции.

Минерализация пробы. Промытый растительный материал высушивали при $55^{\circ} \mathrm{C}$ до постоянного веса и измельчали. Около 1 г пробы взвешивали в тигель, добавляли 0,1 г $\mathrm{CaO}$, смачивали насыщенным раствором $\mathrm{Ca}(\mathrm{OH})_{2}$ и сушили при $55^{\circ}$. Пробу озоляли в муфельной печи при $600^{\circ}$. Охлажденную золу растворяли в 25 м $33 \%$-ной хлорной кислоты и разбавляли до 100 мл.

Потенциометрическөе определение. Применялся потенциометр ЛПУ-06 со сравнительным электродом. В качестве селектрода использован электрод с мембраной из $\mathrm{LaF}_{3}$ и с прибавкой $0,25-0,5 \% \cdot \mathrm{Eu}^{3+}$. $\mathrm{pH}$ раствора определена рН-метром типа 340.

Реактивы. $3 M$ буферный раствор ацетата аммония: 231 ᄅ $\mathrm{CH}_{3} \mathrm{COONH}_{4}$ растворяли в воде, pH $5,7-5,8$ устанавливали при помощи добавления ледяной уксусной кислоты; окончательный объем $-1 \Omega$.

$10^{-1} M$ стандартный раствор фторида: 2,1 г $\mathrm{NaF}$ растворяли в воде, добавляли 100 мл буферного раствора ацетата аммония и разбавляли до $500 \mathrm{\mu}$. Из полученной смеси при помощи соответствующего разбавления изготовляли $10^{-2}, 10^{-3}, 10^{-4}$ и $10^{-5} M$ растворы. Для coхранения ионной концентрации добавляли буферный раствор. Например, для изготовления $10^{-2} M$ раствора брали $50 \mathrm{M} \quad 10^{-1} \mathrm{M}$ исходного и $90 \mu \Omega$ буферного растворов и разбавляли водой до $500 \mathrm{M}$.

Остальные реактивы представляли собой смеси химически чистых веществ - 25\% -ный $\mathrm{NH}_{4} \mathrm{OH}, 33 \%$-ный $\mathrm{HClO}_{4}$ и $\mathrm{CaO}$.

Для потенциометрического определения $\mathrm{F}^{-}$брали 20 мл раствора, полученного при растворении зольного остатка прөбы, нейтрализовали его концентрированным $\mathrm{NH}_{4} \mathrm{OH}$ в присутствии фенолфталеина и добавляли 5 мл буферного раствора. $\mathrm{pH} 4-6$ проверяли рН-метром.

Данные потенциометрического определения сравнивались с калибровочной кривой, составленной с помощью стандартных растворов $\mathrm{NaF}$.

На основании найденной концентрации $\mathrm{F}^{-}$рассчитано содержание фторида в растительной пробе в миллиграммах на 1 ке высушенного материала.

\section{Результаты определений}

Так как сосны - один из наиболее чувствительных к соединениям фтора видов деревьев, представляет интерес определение содержания фторида в их хвое как в загрязненных районах, так и районах с чистым воздухом. Для этого в июне 1975 г. с одно- и двухгодичных отростков сосны собрали хвою.

Данные табл. 1 свидетельствуют о том, что в районе МаардуКаллавере, где воздух сильно загрязнен фтористыми соединениями [24], содержание фторида в хвое сосен примерно в 3 раза выше, чем в хвое сосен, растущих в других местах. Характерно, что у деревьев здесь иголки хвои имеют типичные признаки повреждения фторидами омертвевшие вершины, причем на гранище омертвевшей и живой части ткани - темно-коричневая полоса [25]. В хвое сосен, растущих вдоль Ленинградского шоссе около Маардуского химкомбината, содержание фторида низкое, несмотря на загрязненность этой местности соединениями фтора. Можно предположить, что у чахлых, полузасохших растений обмен веществ замедлен и аккумуляция фтористых соединений слаба. 
В табл. 2 приведены данные сравнения содержания фторида в разновозрастной хвое сосен.

Значительной разницы в содержании фторида в разновозрастной хвое не обнаружено. Возможно, соединения фтора аккумулируются в хвое сосен до определенного равновесия и возраст иголок на формирование содержания фторида не влияет.

Содержание фторида в травянистых растениях представляет интерес как возможный источник, вызывающий заболевание сельскохозяйственных животных флюорозом.

Пробы трав собирали в районе, загрязненном фтористыми соединениями, и в чистом районе (табл. 3 ).

Таблица 1

\section{Содержание фтора в хвое сосны}

\begin{tabular}{l|c|c}
\hline Местонахождение & Возраст дерева & $\mathrm{F}^{-}$, мг/кг \\
\hline
\end{tabular}

Между Маарду и Каллавере

Ленинградское шоссе, в 25 км от Таллина

Мустамяэ

Нымме

Мyуга

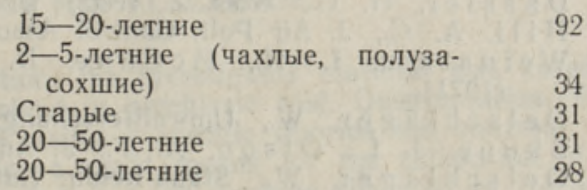

таблица 2

Содержание фторида в разновозрастной хвое сосен

\begin{tabular}{l|l|c}
\hline \multirow{2}{*}{ Местонахождение } & \multicolumn{2}{|c}{ Содержание $\mathrm{F}^{-}$, мг/ка } \\
\cline { 2 - 3 } & Одногодичная хвоя & Двухгодичная хвоя \\
\hline
\end{tabular}

Между Маарду и Каллавере

Ленинградское шоссе, в 25 км от Таллина

Myyra

Нымме

97

97

35

32

32

31

28

Содержание $\mathrm{F}^{-}$в травянистых растениях, мг/кг

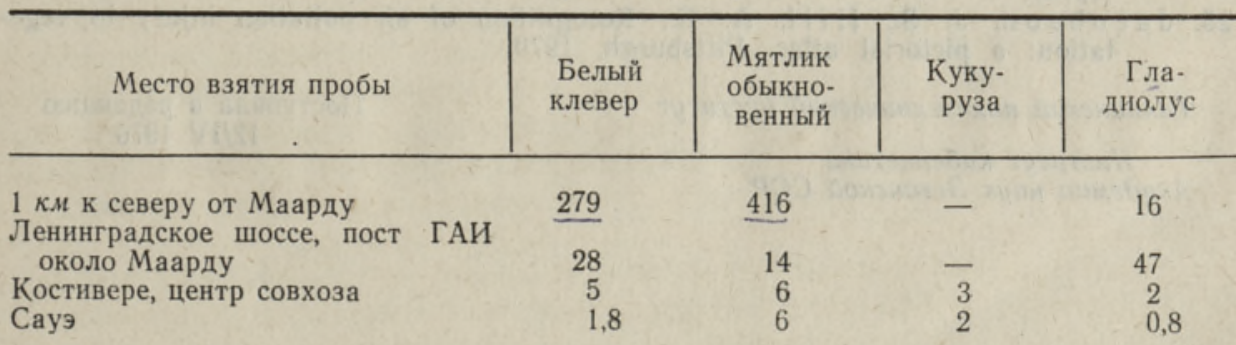

Данные табл. 3 показывают, что кормовые травы в местности с загрязненным воздухом (особенно вблизи Маардуского химкомбината) представляют опасность для животных. 


\section{Выводы}

1. Для быстрого определения накопленного в растениях фторида использована минерализация пробы с растворением зольного остатка в хлорной кислоте и последующим измерением фторида при помощи фторселективного электрода.

2. Количество накопленного в хвое сосен фторида зависит от биологического состояния сосен и лишь приблизительно отражает загрязненность окружающего воздуха.

3. Травянистые растения накапливают фториды из загрязненного воздуха в количестве, опасном для животных.

\section{ЛИТЕРАТУ РА}

1. B a iley, B. W., J. Air Poll. Control Assoc., 8, 601 (1969).

2. Prival, M. J., Fisher, F., Environment, 3, 25 (1973).

3. Cross, F. L. Jr., Ros s, R. W., J. Air Poll. Control Assoc., 15, 1 (1969).

4. Quellmalz, E., Oelschläger, W., Staub-Reinh. Luft, 5, 206 (1971).

5. D äs sle r, H. G., Wiss. Z. Techn. Univ. Dresden, 4, 1171 (1971).

6. Hill, A. C., J. Air Poll. Control Assoc., 5, 331 (1969).

7. Weinstein, L. H., McCune, D. C., J. Air Poll. Control Assoc., 7, 410 (1971).

8. Oels chläger, W., Umweltforschung, 58, 29 (1971).

9. Shupe, J. L., Ols on, A. F., J. Amer. Vet. Med. Assoc., 2, 167 (1971).

10. Oelschläger, W., Staub-Reinh. Luft, 11, 457 (1971).

11. C a t c ott, E. J., Verunreinigung Luft. Weinheim/Bergstr., 217 (1964).

12. Л уйг а П. О., Лийв Р. Г., О т т Р. Э., Сийрде А. К., Хельп К. Д., Тр. Таллинск. политехн. ин-та, 359, 63 (1974).

13. Ильинская Г. И., Л евков Е. Г., Левкова А. С., Пеховольская Д. И., ЖAX, 3, 614 (1973).

14. С а ли а мон Г. С., Попе льков ск ая М. В., Гиг. и сан., 4,65 (1973).

15. Warner, T. B., Bressa n, D. J., Anal. Chim. Acta, 1, 165 (1973).

16. Ба у сов Н Н. В., Бам бу ров В. Г., Манакова Л. И., С ивопляс А. П., ЖAX, 10, 2042 (1973).

17. Пунгор Э., ЖАХ, 6,1182 (1970).

18. Levaggi, D. A., Oyung, W., Feldstein, M., J. Air Poll. Control Assoc., 5, 277 (1971).

19. Thom a s, M. D., A m tower, R. E., J. Air Poll. Control Assoc., 6, 439 (1969).

20. Tentative method of analysis for fluoride content of the atmosphere and plant tissues (semiautomated method). Health Labor. Sci., 2, 84 (1969).

21. Stuart, J. L., Analyst, 95, 1032 (1970).

22. Голутв ин а М. М., Кононыкина И. И., Р ябкин В. П., Гиг. и сан., 5,64 (1970).

23. Evans, L., Hoyle, R. D., Macasicilf, J. B., New Zealand J. Soc., 13, 143 (1969).

24. Л и й в Р., О т т Р., Л уй га П., Пикков В., Изв. АН ЭССР. Хим. Геол., 23, 208 (1974).

25. Jacobson, J. S., Hill, A. C., Recognition of air pollution injury to vegetation: a pictorial atlas. Pittsburgh, 1970.

Таллинский политехнический институт Ннститут кибернетики

Поступила в редакцию 12/IV 1976

\section{Академии наук Эстонской ССР}


Aino SIIRDE, P. LUIGA

\section{TAIMEDE FLUORIIDISISALDUSE MÄARAMINE FLUORIIDSELEKTIIVSE ELEKTROODI ABIL}

Artiklis on esitatud suhteliselt kiire meetod, mis võimaldab taimedesse akumuleerunud fluoriidi koguse järgi hinnata ōhu saastatust fluoriühenditega ja kontrollida fluoriidisisalduse seisukohast loomatoidu kvaliteeti. Taimede fluoriidisisalduse määramiseks uuritav materjal tuhastati temperatuuril $600^{\circ} \mathrm{C}$ ja lahustati perkloorhappega. Lahusest määrati fluoriid fluoriidselektiivse elektroodi abil (pH vahemikus 4-6). Uurimisel kasutatud männiokaste fluoriidisisaldus oli $24-97 \mathrm{mg} / \mathrm{kg}$ (sõltuvalt ümbritseva ōhu saastatusest ja puude seisundist), rohttaimede fluoriidisisaldus saastatud ōhuga piirkonnas $416 \mathrm{mg} / \mathrm{kg}$, puhta öhuga aladel $1-6 \mathrm{mg} / \mathrm{kg}$.

Aino SIIRDE, P. LUIGA

\section{DETERMINATION OF FLUORIDES IN VEGETATION WITH A FLUORIDE ION ELECTRODE}

To determine the fluorides in vegetation, the investigated material was ashed by combustion at $600^{\circ} \mathrm{C}$, and thereafter dissolved in perchloric acid. Determination of the fluoride ion was performed at $\mathrm{pH} 4$ to 6 , using a specific fluoride ion electrode. The method is comparatively fast and provides a rapid means for the estimation of the pollution level of ambient air. It is also well suited for checking the level of contamination of forage.

The content of fluorides in the pine needles was between 24 and $97 \mathrm{mg} / \mathrm{kg}$, dependent on the pollution level of the ambient air and the condition of the trees. The content of fluorides in the herbaceous plants in the region of polluted air was up to $416 \mathrm{mg} / \mathrm{kg}$, and in the clean air region only 1 to $6 \mathrm{mg} / \mathrm{kg}$. 